\title{
Pengembangan Model Capacitated Maximal Covering Location Problem (CMCLP) Dalam Penentuan Lokasi Pendirian Gudang
}

\author{
Putu Eka Dewi Karunia Wati*, Hilyatun Nuha \\ Teknik Industri, Universitas 17 Agustus 1945 Surabaya \\ Jl. Semolowaru 45 Surabaya, 031-5931800/031-5927817 \\ *Korespondensi penulis, surel: putu_ekadkw@untag-sby.ac.id
}

\begin{abstract}
A strategic location is a place for facility location that built and is able to give maximum advantages for the company. The problem of deciding location is important in optimization area. In general, the solution of that problem focuses on facility placement that is able to minimize or maximizing distribution time, distance, transportation cost or another parameter. Therefore, an appropriate model is needed to determine the strategic location of warehouse establishment. The purpose of this research is to develop a Capacitated Maximal Covering Location Problem (MCLP) model that can be used in determining the location of warehouse establishment that can maximize the number of demands that can be served. From the model, the company not only finds the optimum location to establish the facility but also they can know the number of goods allocated from the distribution center to each demand point as well as the maximum number of demand that can be served.
\end{abstract}

Keywords: Allocation goods, Capacitated Maximal Covering Location Problem (MCLP), Facility Location.

\begin{abstract}
Abstrak
Lokasi strategis adalah sebuah penempatan lokasi fasilitas sehingga fasilitas yang dibangun dapat memberikan keuntungan maksimal bagi perusahaan tersebut. Masalah penentuan lokasi juga merupakan masalah yang sangat penting dalam bidang optimasi. Pada umumnya solusi untuk masalah tersebut fokus pada penempatan fasilitas yang dapat meminimalkan ataupun memaksimalkan waktu distribusi barang, jarak, biaya transportasi atau beberapa parameter lainnya. Oleh karena itu, diperlukan sebuah model yang yang tepat untuk menentukan lokasi strategis pendirian gudang. Tujuan dari penelitian ini adalah untuk mengembangkan sebuah model Capacitated Maximal Covering Location Problem (CMCLP) yang dapat digunakan dalam menentukan lokasi pendirian gudang yang dapat memaksimalkan jumlah permintaan yang dapat terpenuhi. Dari model tersebut, perusahaan bukan hanya menemukan lokasi optimum untuk mendirikan fasilitas tetapi juga dapat mengetahui jumlah alokasi barang dari distribution center ke setiap titik permintaan serta jumlah maksimal permintaan yang dapat terpenuhi.
\end{abstract}

Kata kunci: Alokasi Barang, Capacitated Maximal Covering Location Problem (CMCLP), Lokasi Fasilitas.

\section{Pendahuluan}

Perkembangan sebuah perusahaan dipengaruhi oleh beberapa faktor, salah satunya adalah faktor lokasi. Salah satu keputusan yang paling penting yang dibuat oleh perusahaan adalah di mana perusahaan tersebut akan menempatkan kegiatan operasional mereka. Oleh karena itu, perusahaan harus memiliki strategi lokasi yang tepat agar kegiatan operasional perusahaan tersebut dapat berjalan dengan lancar. Lokasi yang strategis yang dimaksudkan adalah sebuah penempatan lokasi fasilitas 
sehingga fasilitas yang dibangun dapat memberikan keuntungan maksimal bagi perusahaan tersebut. Pemilihan lokasi pada umumnya memengaruhi biaya yang dikeluarkan oleh perusahaan, baik biaya tetap maupun biaya variabel [1]. Pada umumnya biaya alokasi / biaya distribusi merupakan biaya yang paling terpengaruh oleh lokasi yang dipilih sehingga dapat dikatakan bahwa faktor lokasi akan sangat memengaruhi keuntungan perusahaan secara keseluruhan. Masalah penentuan lokasi juga merupakan masalah yang sangat penting dalam bidang optimasi dan pada umumnya solusi untuk masalah tersebut berfokus pada penempatan fasilitas yang dapat meminimalkan ataupun memaksimalkan waktu distribusi barang, jarak, biaya transportasi atau beberapa parameter lainnya [2].

Salah satu subclass dari masalah penentuan lokasi fasilitas adalah Covering Location Problem (CLP). Walaupun model covering ini bukan merupakan sebuah model yang baru, model ini menjadi alat yang sangat menarik untuk digunakan dalam penelitian yang membahas mengenai lokasi. Penerapan model covering sudah banyak diaplikasikan dalam dunia nyata terutama untuk pelayanan dan fasilitas darurat [3]. Pada Covering Model, terdapat coverage distance atau jarak pemenuhan. Coverage distance inilah yang akan menjadi penentu fasilitas tersebut akan dibuka atau ditutup. Selain itu, pada model ini pelanggan hanya dapat dilayani setidaknya oleh satu fasilitas yang dibangun berdasarkan coverage distance-nya.

Dalam suatu perusahaan, gudang merupakan hal yang sangat penting bagi proses aliran barang di dalam ataupun di luar perusahaan. Fungsi dari gudang itu sendiri adalah sebagai tempat penyimpanan baik barang mentah (raw material), barang setengah jadi (intermediate), atau produk jadi (finish goods). Menurut Guha, et al. [4], gudang adalah bagian dari system logistik perusahaan yang menyimpan produk-produk (raw material, parts, goods in process, finished goods) pada dan antara titik sumber (point of origin) dan titik konsumsi (point of cumsumption), dan menyediakan informasi kepada manajemen mengenai status, kondisi, dan disposisi dari item-item yang disimpan. Lokasi gudang yang kurang tepat akan menambah biaya pengiriman ataupun biaya perjalanan yang dikeluarkan oleh perusahaan. Selain itu, lokasi gudang yang kurang tepat akan menimbulkan keterlambatan dalam pengiriman yang berakibat ketidakpuasan pelanggan terhadap service yang diberikan oleh perusahaan tersebut. Oleh karena itu, diperlukan sebuah perhitungan dan analisa yang tepat dalam pengambilan keputusan lokasi pendirian gudang.

Penentuan lokasi gudang dengan menggunakan model CMCLP yang sederhana sebelumnya telah dibahas dalam penelitian Current and Storbeck [5]. Pada penelitian tersebut, model CMCLP digunakan untuk meminimasi jumlah permintaan yang tidak dapat dipenuhi oleh fasilitas yang didirikan. Model tersebut hanya memiliki tiga fungsi kendala (batasan) yang berkaitan dengan kapasitas gudang yang memiliki batasan tertentu, jumlah gudang yang akan dibangun, dan fungsi kendala yang menandakan fasilitas akan dibuka atau ditutup. Salah satu penelitian yang mengembangkan model dari Current and Storbeck [5] yaitu penelitian Pirkul and Schilling [6]. Pada penelitian tersebut model CMCLP bertujuan untuk meminimasi jumlah permintaan yang tidak dapat dipenuhi oleh fasilitas yang dibangun dengan mempertimbangkan enam fungsi kendala (batasan) di mana dua di antaranya merupakan binary constraints. Pada penelitian tersebut hanya memiliki variable keputusan yang berupa bilangan biner yang menjelaskan penentuan fasilitas mana yang akan dibuka ataupun ditutup serta menentukan permintaan di daerah mana saja yang dapat dipenuhi oleh fasilitas yang dibangun.

Berdasarkan penelitian terdahulu menunjukkan penelitian model CMCLP telah dilakukan oleh beberapa peneliti. Tetapi penelitian model CMCLP belum 
mempertimbangkan variabel keputusan jumlah alokasi barang dari fasilitas yang dibangun ke setiap titik permintaan. Pada penelitian ini dilakukan pengembangan model sebelumnya dengan menambahkan beberapa fungsi kendala yang dapat menghasilkan variabel keputusan berupa sebuah nilai yang berupa jumlah alokasi barang dari fasilitas yang dibangun ke setiap titik permintaan. Sehingga pada penelitian ini model yang dikembangkan bukan hanya dapat menentukan fasilitas mana saja yang akan dibangun, tetapi juga dapat diketahui jumlah barang yang akan dikirim dari fasilitas tersebut ke setiap titik permintaan yang ditandai.

\section{Metode Penelitian}

Model CMCLP yang dibangun pada penelitian ini bersifat deterministik. Perbedaan model deterministik dan probabilistik dapat diketahui dari sifat permintaannya. Apabila permintaannya dapat diketahui dengan pasti, maka digunakan deterministik model untuk menyelesaikan masalah tersebut. Sebaliknya, apabila jumlah permintaannya berubah-ubah atau tidak dapat diprediksi, maka digunakan probabilistik model dalam menyelesaikan masalah lokasi tersebut [7]. Selain bersifat deterministik, model yang dibangun pada penelitian ini juga berupa single product (produk yang terdapat di dalam gudang ataupun yang akan dialokasikan ke setiap titik permintaan adalah sejenis) dan single echelon (proses alokasi hanya satu tingkat saja, dari distribution center ke demand point) [8].

Algoritma matematika yang digunakan dalam penelitian ini adalah Mixed Integer Linier Programming (MILP). Linear Programming (LP) merupakan teknik dalam manajemen sains yang digunakan untuk menentukan cara optimal untuk mencapai tujuan, disesuaikan dengan batasan, dan berada dalam kasus di mana semua hubungan matematika adalah linear. Sedangkan MILP merupakan bagian dari $L P$ di mana Jika variabel keputusan yang digunakan sebagian berupa bilangan bulat dan sebagian lagi berupa bilangan pecahan [9].

Pada pengembangan model CMCLP menggunakan asumsi yaitu lokasi kandidat pendirian $D C$ juga merupakan titik permintaan. Sehingga, jumlah permintaan pada daerah yang menjadi lokasi terpilih pendirian $D C$ dapat dipasok oleh $D C$ pada daerah tersebut. Akan tetapi, tidak menutup kemungkinan daerah yang dipilih untuk membangun salah satu $D C$ tersebut permintaannya dipenuhi oleh $D C$ lainnya. Pada umumnya model CMCLP menggunakan parameter jarak ataupun waktu untuk sebagai salah satu faktor penentu apakah kandidat $D C$ dapat dibuka atau tidak. Pada penelitian ini digunakan faktor jarak sebagai parameter sama seperti yang terdapat pada penelitian sebelumnya. Formulasi matematika untuk model CMCLP pada penelitian ini dapat dilihat berikut ini:

\section{Fungsi Tujuan}

\section{Fungsi Kendala}

$$
\text { Maximize } \quad \sum_{j-J} \sum_{i=I} Q_{i j} X_{i j} Y_{j}
$$

$$
\begin{aligned}
& \sum_{j=J} y_{j} \leq P \\
& \sum_{j=J} X_{i j} \geq 1
\end{aligned}
$$




$$
\begin{array}{cc}
X_{i j} \leq y_{j} & \forall i \in I, \forall j \in J \\
\sum_{i=I} Q_{i j} X_{i j} \leq K_{j} Y_{j} & \forall j \in J \\
\sum_{j=J} Q_{i j} X_{i j} \geq d_{i} & \forall i \in I \\
Q_{i j} \leq X_{i j} x M & \forall i \in I, \forall j \in J \\
y_{j}=[0,1] & \forall j \in J \\
X_{i j}=[0,1] & \forall i \in I, \forall j \in J
\end{array}
$$

Fungsi tujuan (1) yaitu memaksimalkan kebutuhan yang dapat di cover oleh $D C$ yang dibangun. Fungsi kendala (2) menjelaskan bahwa jumlah maksimal $D C$ yang akan dibangun. Fungsi kendala (3) dan (4) menjelaskan setidaknya kebutuhan dipenuhi oleh $D C$ yang dibangun oleh $D C j$. Fungsi kendala (5) menjelaskan jumlah barang yang akan dikirim dari DC $\mathrm{j}$ ke demand node $\mathrm{k}$ tidak melebihi ketersediaan barang yang terdapat di DC j. Fungsi kendala (6) menjelaskan mengenai jumlah barang yang dikirimkan minimal harus sesuai dengan jumlah kebutuhan yang terdapat pada setiap titik permintaan. Kendala (7) digunakan ketika demand node $\mathrm{k}$ dipenuhi oleh DC $\mathrm{j}$. Sedangkan untuk kendala (8) dan fungsi kendala (9) merupakan binary constraint yaitu fungsi kendala yang menandakan $D C j$ dibuka ataupun ditutup dan barang tersebut dialokasikan ke titik permintaan atau tidak.

\section{Hasil dan Pembahasan}

\subsection{Numerical Experiment}

Untuk melakukan uji coba terhadap model yang dikembangkan, maka dilakukan percobaan numerik dengan menggunakan beberapa data dan simulasi model menggunakan software LINGO 15.0. Untuk melakukan pengujian terhadap model yang dibangun dan membandingkan dengan penelitian sebelumnya, digunakan data yaitu jumlah maksimal $D C$ yang dibangun yaitu 3 buah $D C$ di mana kapasitas masing-masing $D C$ yaitu 1500 unit. Batasan maksimum jarak yang dapat di-cover adalah $36 \mathrm{~km}$. Sedangkan untuk jarak antara kandidat $D C$ dan demand point serta jumlah permintaan di setiap demand point dapat dilihat pada Tabel 1.

Dengan menggunakan data pada Tabel 1, kemudian dilakukan simulasi model yang dibangun, maka diperoleh hasil maksimal demand yang dapat terpenuhi dengan membangun $3 D C$ yaitu 3125 unit sesuai dengan kebutuhan yang ada pada setiap titik permintaan. $D C$ yang dibangun yaitu $D C 1,2$, dan 3 dengan jumlah alokasi barang dari setiap $D C$ yang didirikan ke setiap demand point dapat dilihat pada Tabel 2.

Berdasarkan Tabel 2, diketahui bahwa DC 1 memasok hamper ke setiap titik permintaan. Apabila kembali diperhatikan pada Tabel 1 sebelumnya, dapat dilihat jarak antara $D C 1$ dengan titik-titik permintaan yang lainnya tidak sejauh $D C$ yang lainnya, sehingga akan memengaruhi kemampuan meng-cover dari $D C$ 1. Begitu pula dengan $D C 2$ yang memasok lokasi permintaan di daerah berdirinya $D C 2$ karena jaraknya merupakan jarak coverage terpendek dan memasok ke demand point 4 karena jarak ke demand point 4 memiliki jarak terpendek ke-2 dari DC 2 dibandingkan dengan titik permintaan lainnya. Untuk $D C 3$ memasok permintaan yang terdapat di demand 
point 1 dan demand point 3 dikarenakan demand point tersebut yang permintaannya belum terpenuhi oleh $D C 1$ dan $D C 2$.

Tabel 1 Data Jarak antara DC dan demand point serta permintaan di setiap demand point

\begin{tabular}{|c|c|c|c|c|c|c|c|c|c|}
\hline & \multicolumn{8}{|c|}{ Demand Point } \\
\hline & & 1 & 2 & 3 & 4 & 5 & 6 & 7 & 8 \\
\hline \multirow{8}{*}{$\begin{array}{c}\text { Kandidat } \\
D C\end{array}$} & 1 & 0 & 20 & 15 & 30 & 17 & 25 & 12 & 20 \\
\hline & 2 & 20 & 0 & 48 & 27 & 29 & 49 & 58 & 26 \\
\hline & 3 & 15 & 48 & 0 & 30 & 12 & 15 & 27 & 42 \\
\hline & 4 & 30 & 27 & 30 & 0 & 11 & 45 & 28 & 15 \\
\hline & 5 & 17 & 29 & 12 & 11 & 0 & 29 & 34 & 57 \\
\hline & 6 & 25 & 49 & 15 & 45 & 29 & 0 & 28 & 45 \\
\hline & 7 & 12 & 58 & 27 & 28 & 34 & 28 & 0 & 37 \\
\hline & 8 & 20 & 26 & 42 & 15 & 57 & 45 & 37 & 0 \\
\hline \multicolumn{2}{|c|}{$\begin{array}{c}\text { Jumlah } \\
\text { Permintaan }\end{array}$} & 600 & 450 & 375 & 420 & 290 & 300 & 290 & 400 \\
\hline
\end{tabular}

Tabel 2 Jumlah Alokasi Barang dari DC ke demand point

\begin{tabular}{ccccccccc}
\hline \multirow{2}{*}{$D C$} & \multicolumn{7}{c}{ Demand Point } \\
\cline { 2 - 8 } & 1 & 2 & 3 & 4 & 5 & 6 & 7 & 8 \\
\hline 1 & 4 & & 215 & & 290 & 300 & 290 & 400 \\
2 & & 450 & & 420 & & & & \\
3 & 596 & & 160 & & & & & \\
\hline
\end{tabular}

\subsection{Analisis Sensitivitas}

Analisis sensitivitas digunakan untuk mengukur sejauh mana model yang dibangun dapat memecahkan masalah dan sejauh mana parameter yang digunakan dapat memengaruhi hasil dari running model yang telah dibangun. Pada penelitian kali ini dilakukan analisis sensitivitas dengan mengubah parameter permintaan yang terdapat pada setiap demand point. Pada parameter permintaan akan ditingkatkan sebanyak 50\% dan diturunkan sebanyak 50\%.

Berdasarkan model yang dibangun, maka dilakukan sebuah analisis sensitivitas dengan menggunakan data permintaan yang naik dan turun sebanyak 50\%. Apabila permintaan naik menjadi 50\%, pembangunan 3 buah $D C$ dengan kapasitas sebesar 1500 unit tidak mampu meng-cover semua demand dikarenakan jumlah barang yang tersedia di gudang lebih sedikit dari pada jumlah permintaannya. Oleh sebab itu, apabila demand meningkat menjadi 50\%, maka $D C$ yang dibangun harus ditambah menjadi empat ataupun menambah kapasitas tiap unit $D C$ yang dibangun.

Apabila terjadi penurunan jumlah permintaan sebanyak 50\%, maka permintaan yang ada pada setiap demand node dapat di-cover karena jumlah unit yang tersedia pada 3 gudang yang dibangun masih dapat memasok permintaan yang terdapat pada setiap demand node. Dengan menggunakan model yang dibangun, maka didapatkan jumlah maksimal demand yang dapat di-cover apabila terjadi penurunan permintaan sebanyak 50\% yaitu sebesar 1563 unit. Dengan mendirikan $3 D C$ yaitu $D C$ 1,2, dan 4 , maka jumlah alokasi barang dapat dilihat pada Tabel 3. 
Tabel 3 Jumlah Alokasi Barang dari DC ke demand point (permintaan menurun 50\%)

\begin{tabular}{ccccccccc}
\hline \multirow{2}{*}{ DC } & \multicolumn{7}{c}{ Demand Point } \\
\cline { 2 - 9 } & 1 & 2 & 3 & 4 & 5 & 6 & 7 & 8 \\
\hline 1 & & 225 & 188 & 210 & 6 & 150 & 145 & 200 \\
2 & 15 & & & & & & & \\
4 & 285 & & & & 139 & & & \\
\hline
\end{tabular}

Berdasarkan Tabel 3, dapat dilihat alokasi barang terbanyak dilakukan oleh $D C$ 1 dikarenakan jarak antara $D C 1$ dengan setiap demand node masih dalam coverage distance dan kapasitas $D C$ nya masih mampu memenuhi sebagian besar permintaan yang terdapat pada setiap demand node.

\section{Simpulan}

Berdasarkan numerical experiment yang telah dilakukan, maka dapat diketahui bahwa model yang dibangun dapat memberikan solusi dalam penentuan lokasi sejumlah gudang, yang mana gudang yang dibangun tersebut dapat memenuhi permintaan yang terdapat di seluruh demand node. Berdasarkan hasil simulasi, dari delapan kandidat $D C$ yang dibangun, dengan membangun $3 D C$ yaitu DC 1, 2, dan 3 sudah mampu mengcover semua permintaan yang ada. Kemampuan memasok dari ketiga DC yang dibangun, bergantung pada jumlah permintaan dan coverage distance untuk setiap $D C$. Terdapat beberapa parameter yang dapat memengaruhi hasil keputusan dalam model yang dibangun antara lain yaitu jumlah permintaan dan kapasitas dari gudang yang akan dibangun. Apabila jumlah permintaan lebih banyak dari kapasitas DC yang dibangun, maka solusinya adalah meningkatkan jumlah DC yang didirikan ataupun meningkatkan kapasitas tiap DC yang dibangun. Sedangkan apabila terjadi penurunan permintaan, tidak berpengaruh secara signifikan jumlah demand yang dapat di-cover, selama jumlah penurunan masih sesuai dengan kapasitas tiap gudang. Dengan diketahuinya jumlah barang yang akan dikirimkn dari DC ke setiap titik permintaan, maka untuk penelitian selanjutnya dapat mempertimbangkan jenis vehicle yang digunakan sehingga dapat diketahui frekuensi pengiriman barang dari fasilitas yang didirikan ke setiap titik permintaan. Saran untuk penelitian selanjutnya adalah melakukan pengembangan model MCLP dengan menghilangkan asumsi lokasi kandidat pendirian $D C$ juga merupakan titik permintaan.

\section{Daftar Notasi}

Index

$j \quad=$ Indeks untuk kandidat distribution center $(D C)$

$i=$ Indeks untuk demand node

$s=$ Indeks untuk service distance

\section{Parameter}

$d_{i}=$ Jumlah kebutuhan yang terdapat pada node $i$

$K_{j} \quad=\quad$ Kapasitas barang di $D C j$

$s_{i j}=$ Jarak antara $D C j$ ke demand node $i$

$S=$ Jarak Maksimum yang dapat di-cover

$P \quad=$ Jumlah gudang yang akan di bangun 


\section{Variabel Keputusan}

$$
\begin{aligned}
h_{i j} & =\left\{\begin{array}{c}
1 \text { Jika } s_{i j} \leq S \\
0 \text { Jika tidak }
\end{array}\right. \\
X_{i j} & =\left\{\begin{array}{r}
1 \text { Jika demand di node } \text { i dipenuhi oleh } D C j \\
\text { 0 Jika tidak }
\end{array}\right. \\
y_{j} & =\left\{\begin{array}{r}
1 \text { Jika fasilitas didirikan DC } j \\
0 \text { Jika tidak }
\end{array}\right. \\
Q_{i j} & =\text { Barang yang dikirim dari } D C j \text { ke demand node } i
\end{aligned}
$$

\section{Referensi}

[1] D. M. Lambert and J. R. Stock, Strategic logistics management vol. 69: Irwin Homewood, IL, 1993.

[2] M. S. Daskin, Network and discrete location: models, algorithms, and applications: John Wiley \& Sons, 2011.

[3] B. Zhang, J. Peng, and S. Li, "Covering location problem of emergency service facilities in an uncertain environment," Applied Mathematical Modelling, vol. 51, pp. 429-447, 2017.

[4] S. Guha, R. Hassin, S. Khuller, and E. Or, "Capacitated vertex covering," Journal of Algorithms, vol. 48, pp. 257-270, 2003.

[5] J. R. Current and J. E. Storbeck, "Capacitated covering models," Environment and planning B: planning and Design, vol. 15, pp. 153-163, 1988.

[6] H. Pirkul and D. A. Schilling, "The maximal covering location problem with capacities on total workload," Management Science, vol. 37, pp. 233-248, 1991.

[7] R. Blanquero, E. Carrizosa, and G. Boglárka, "Maximal covering location problems on networks with regional demand," Omega, vol. 64, pp. 77-85, 2016.

[8] O. Berman, J. Kalcsics, and D. Krass, "On covering location problems on networks with edge demand," Computers \& Operations Research, vol. 74, pp. 214$227,2016$.

[9] A. Kamal, R. A. Vinarti, and W. Anggraeni, "Optimasi Persediaan Perusahaan Manufaktur dengan Metode Mixed Interger Linear Programming," Skripsi. Program Studi Sistem Informasi. Institut Teknologi Sepuluh Nopember, 2012. 